\title{
ECTOMYCORRHIZAL FUNGI INCREASED EARLY GROWTH OF Shorea balangeran (Korth.) Burck UNDER NURSERY AND FIELD CONDITIONS IN DEGRADED PEAT SWAMP FOREST
}

(Fungi Ektomikoriza Meningkatkan Pertumbuhan Awal Shorea Balangeran (Korth.) Burck pada Kondisi Persemaian dan Lapangan di Hutan Rawa Gambut Terdegradasi)

\section{by / oleh :}

Maman Turjaman ${ }^{1}$, Hideyuki Saito ${ }^{2}$, Erdy Santoso ${ }^{1}$, Agung Susanto $^{3}$, Sampang Gaman $^{3}$, Suwido Hester Limin $^{3}$, Masato Shibuya ${ }^{2}$, Kunihide Takahashi², Yutaka Tamai ${ }^{2}$, Mitsuru Osaki $^{2}$ and Keitaro Tawaraya ${ }^{4}$

${ }^{1}$ Forest and Nature Conservation Research \& Development Centre, Ministry of Forestry, Bogor 16610, Indonesia, E-mail : turjaman@yahoo.com.sg ${ }^{2}$ Graduate School of Agriculture, Hokkaido University, Sapporo 060-8589, Japan ${ }^{3}$ Faculty of Agriculture, University of Palangka Raya, Palangka Raya 73112, Indonesia ${ }^{4}$ Faculty of Agriculture, Yamagata University, Tsuruoka 997-8555, Japan

\begin{abstract}
Seedlings of Shorea balangeran (Korth.) Burck were inoculated with spores of four ectomycorrhizal (ECM) fungi, Calvatia sp., Boletus sp., Scleroderma sp. and Strobilomyces sp., and were grown in pots containing sterilized peat soil for six months under nursery conditions and transplanted in field conditions. Four ECM fungi were collected from peat soil of Nyaru Menteng, Palangka Raya, Central Kalimantan. Six-months-old inoculated seedlings were transplanted into degraded peat-swamp forest. The ECM fungal colonization was $59-67 \%$ in inoculated seedlings under nursery conditions. Colonization of S. balangeran (Korth.) Burck increased shoot height, stem diameter, leaf number, and shoot fresh and dry weight 6 months after transplanting under nursery conditions. Shoot height, stem diameter, leaf number and survival rates of $S$. balangeran (Korth.) Burck were higher in the inoculated seedlings 40 months after transplanting under field conditions than in the control seedlings. It is suggested that inoculation of indigenous ECM fungi in native tree species is useful for reforestation of degraded peatswamp forests.
\end{abstract}

Keywords : ectomycorrhiza, spore, Shorea balangeran (Korth.) Burck, peat-swamp forest, nursery and field.

\section{ABSTRAK}

Bibit Shorea balangeran (Korth.) Burck telah diinokulasi oleh empat jenis cendawan ektomikoriza (ECM) Strobilomyces sp., Calvatia sp., Boletus sp., dan Scleroderma sp. selama enam bulan di persemaian dan ditanam 40 bulan pada kawasan hutan rawa-gambut terdegradasi di Kalimantan Tengah. Empat jenis cendawan ektomikoriza berasal dari Nyaru Menteng, Palangka Raya, Kalimantan Tengah. Benih S. balangeran (Korth.) Burck diinokulasi dengan spora empat jenis ECM dan ditumbuhkan pada polybag yang berisi gambut selama enam bulan di persemaian. Bibit $S$. balangeran (Korth.) Burck yang telah berumur enam bulan ditanam pada kawasan hutan rawa-gambut yang terdegradasi. Kolonisasi ektomikoriza Boletus sp. Dan Scleroderma sp. secara signifikan meningkatkan pertumbuhan tinggi dan diameter S. balangeran (Korth.) Burck 40 bulan setelah ditanam di lapangan. Dari hasil penelitian ini bahwa diperlukan inokulasi ECM lokal terhadap pertumbuhan jenis-jenis Dipterokarpa pada kondisi di persemaian untuk mempercepat rehabilitasi kawasan hutan rawa-gambut terdegradasi.

Kata kunci: ektomikoriza, spora, Shorea balangeran (Korth.) Burck, hutan rawa-gambut, persemaian dan lapangan. 


\section{INTRODUCTION}

The biological and economic importance of Dipterocarpaceae lies in the extraordinary dominance of its members over vast areas in tropical rain forests of Southeast Asia (Bawa, 1998). With approximately 510 species and 16 genera, the family may not be particularly large among tropical woody groups. Other families such as Euphorbiaceae, Myrtaceae, Rubiaceae, Annonaceae, and Lauraceae have more taxa than the Dipterocarpaceae, however, they are pan tropical in distribution. Some important genera of Dipterocarpaceae are Shorea, Dryobalanops, Hopea, Vatica, Parashorea and Dipterocarpus (Soerianegara and Lemmens, 1994). Shorea consist of about 194 species and be the greatest diversity occurs in Sumatra (23 species), Mollucas ( 1 species) and Kalimantan (62 species). Unfortunately, their existence is decreasing because of over-exploitation, forest fire and illegal logging. Shorea balangeran (Korth.) Burck is distributed over scattered locations of Bangka, Belitung and Kalimantan islands and attain a height of $30 \mathrm{~m}$ and diameter up to $60 \mathrm{~cm}$. This species is common and occurs often gregarious in tropical peat-swamp forest. S. balangeran (Korth.) Burck is economically important, because it produces a major source of durable wood (heavyweight hardwood) and valuable resin can be obtained from the wood.

Tropical peat-swamp forests have been decreasing due to forest fire, illegal logging, conversion of forests into industrial and agricultural lands, rubber tree and palm oil plantation or forest plantation estate for pulp and paper. Degraded peat-swamp forests are recognized as low values of forest resources without successful natural regeneration and dominated by grassland including fern, sedge or scrub (Page et al., 1999; Kobayashi, 2000). Indonesian government has a program of national movement to accelerate rehabilitation of degraded peat-swamp forests. However, it is not easy to rehabilitate this ecosystem immediately because it is necessary to select and produce high-quality tree seedling species for rehabilitation. Mycorrhizas affect the maintenance of vegetation in various ecosystems, and may play an important role in rehabilitation of degraded peat-swamp forest (Tawaraya et al., 2003).

Dipterocarpaceae, Fagaceae, Pinaceae, and some genera of Myrtaceae are known to form ectomycorrhizas (ECM) (Alexander and Lee, 2005). All Dipterocarpaceae surveyed to date are associated with ECM fungi (Högberg, 1982; Smits, 1994; Lee, 1998), and fungal families with greatest diversity in Southeast Asian dipterocarps forests include the Sclerodermataceae, the Russulaceae, the Boletaceae and the Amanitaceae (Smits, 1994; Sims et al., 1997). ECM fungi may have a great potential for the regeneration of tropical forests Dipterocarpaceae is a large and diverse family, with great ecological amplitude, and ECM dipterocarps are found in a wide range forest types, growing under wide range of nutrient regimes (Smits, 1994; Alexander and Lee, 2005). The ECM formation has been shown to increase plant growth of Shorea curtisii Dyer ex King and S. Leprosula Miq. (Lee and Lim, 1989), S. macroptera Dyer (Turner et al., 1993), Hopea odorata Roxb. and H. helferi Brandis (Yazid et al., 1994) under nursery conditions. However, little is known about the effect of ECM inoculation on the growth of dipterocarps species or Shorea species originated from a peat-swamp forest under nursery conditions.

In tropical forest, the use of ECM Pisolithus tinctorius (Pers.) Coker \& Couch has been tested with Pinus carribaea Borelet in field conditions after three years on savana in Liberia, Africa (Marx et al., 1985). Five ECM fungi increased plant growth of hybrid eucalypts (Eucalyptus urophylla S.T. Blake x E. kirtoniana F. Muell) 50 months after outplanting in a nutrient-poor acidic sandy savanna soil in the Congo, Africa (Garbaye et al., 1988). This kind of field experiment has been already described in temperate area with four ECM species inoculated to Pseudotsuga menziesii (Mirbel) Franco (Douglas Fir) in northern Spain (Pera et al., 1999), and 
ECM Laccaria bicolor (Maire) P.D. Orton inoculated to P. menziesii (Mirbel) Franco (Douglas Fir) in central France (Selosse et al., 2000). However, there are no reports on the effect of ECM inoculation on the growth of Shorea species origin from a peat-swamp forest under field conditions.

Several works have been reported on the type of ECM inoculum used in tropical tree species. Mycelia of ECM have been inoculated to increase plant growth of Hopea spp. (Yazid et al., 1994). Tablet spores of ECM have confirmed to be effective on several eucalypt species (de la Cruz, 1990), Spore suspension of ECM fungi has been tested to tropical tree Eucalyptus urophylla S.T. Blake (Chen et al., 2006) and cuttings of Shorea leprosula Miq. (Omon, 2002), but little work has been undertaken on the inoculation of dipterocarps with fungal spore suspension. Objectives of this study were to investigate the effect of four ECM species inoculation using spore suspension on plant growth of Shorea balangeran (Korth.) Burck under nursery and field conditions. These ECM fungi were chosen because they are native in peat-swamp forest.

\section{MATERIALS AND METHODS}

Seeds of S. balangeran (Korth.) Burck were obtained from Nyaru Menteng arboretum in Central Kalimantan, Indonesia $\left(2^{\circ} 43^{\prime} \mathrm{S} ; 111^{\circ} 38^{\prime} \mathrm{E}\right)$. Peat soil used for the pot experiment was collected from a peat swamp forest in Kalampangan, Palangka Raya, Central Kalimantan $\left(2^{\circ} 13^{\prime}\right.$ $\left.\mathrm{S} ; 113^{\circ} 56^{\prime} \mathrm{E}\right)$. Peat soil was sterilized in a drum by heating over a wood fire for 1 hour. The $\mathrm{pH}$ $\left(\mathrm{H}_{2} \mathrm{O}\right)$ of the peat soil was 3.3, available $\mathrm{P}$ (Bray-1) was $5.91 \mathrm{mg} \mathrm{kg-1}$. A preliminary experiment showed that this sterilization procedure got rid of most of the ECM and pathogenic fungi. Seeds of $S$. balangeran were soaked for two hours and gently washed with running water. These seeds were sown in polyethylene pots (size $15 \mathrm{~cm} \times 10 \mathrm{~cm}$ ) containing $500 \mathrm{~g}$ sterilized peat soils. Pots containing seeds were transferred to a nursery at the University of Palangka Raya, Central Kalimantan. One seedling was grown per pot under a $75 \%$ shading intensity net to control solar radiation.

Fruit bodies of Calvatia sp., Boletus sp., Scleroderma sp. and Strobilomyces sp. were obtained from basidiomes in the field under native trees of S. balangeran at Nyaru Menteng arboretum in Central Kalimantan. Fruit bodies were identified previously by Dr Tamai (Hokkaido University, Japan) in 2002. Each fruit bodies of ECM species were blended in distilled water $(1: 10, \mathrm{v} / \mathrm{v})$ for $60 \mathrm{~s}$ using a blender on low speed. A drop of Tween 80 was added to assist suspension. Inoculation of seedlings was carried out 10 days after germination. Seedlings in each treatment were given $10 \mathrm{ml}$ of spore suspension. The spore suspension was added in a 2-3 cm deep hole near the seedling using a five $\mathrm{ml}$ pipette. All pots were put on bricks in nursery beds to avoid cross contamination and to ensure good drainage. The seedlings were irrigated with tap water everyday and weeds were removed. The following treatments were used: (1) untreated (control), (2) Calvatia sp., (3) Boletus sp., (4) Scleroderma sp. and (5) Strobilomyces $\mathrm{sp}$. There was no mixture ECM in this study because the study would like to know the best one of ECM fungi.

Experiment site was located in Kalampangan zone near Kapuas border, Central Kalimantan. The peat soil at study site has very low $\mathrm{pH}(<4)$, this is assumed due to a high organic matter which producing some organic acid compounds through decomposition process under waterlogged conditions (Tuah et al., 2000). Annual precipitation is 2776 to $3393 \mathrm{~mm} /$ year; mean annual temperature is $30^{\circ} \mathrm{C}$. Natural regeneration was very poor. Native vegetations of this site are dominated by Combretocarpus rotundatus, Melaleuca cajuputi, Polystichum setiferum, Imperata cylindrica, Melastoma sp. and various species of grasses. In November 2002, one 
hundred of seedlings per treatment were planted in Kalampangan. The seedlings were planted individually in planting hole $(15 \mathrm{~cm} \times 15 \mathrm{~cm} \times 15 \mathrm{~cm})$ and a line spacing was $1 \mathrm{~m} \times 1 \mathrm{~m}$. Maintenance of the seedlings after transplanting was each six months in the first year of plantation. Chemical fertilizer was not added in the nursery and the field experiment.

Shoots and roots were harvested six months after being inoculated with ECM fungi. Shoot height, stem diameter, leaf number, and fresh and dry weight were measured. After measuring the fresh weight of shoots, its dry weight was determined after drying at $70^{\circ} \mathrm{C}$ for 72 hours. To calculate the percentage of ECM colonization, roots were cleaned using running water to separate them from the soil and then the root systems were spread on trays. The total number of root tips and the number of ECM short roots were counted under a dissecting microscope.

Verification of ECM colonization was obtained by examining the cross section of root tips (cut manually) under a compound microscope for the presence of mantle and Hartig net (Brundrett et al., 1996). Plant height, leaf number and survival rates were measured 2, 4, 6, 8, 14, $16,19,22$, and 25 months after transplanting in field conditions. Plant height, stem diameter, and survival rates were measured 40 months after transplanting in field conditions. Survival rates were calculated as follows; Survival rates $(\%)=$ number of viable seedlings / number of initial seedlings $100 \times 100$. Data were statistically analyzed using analyses of variance (ANOVA) with the statistical software StatView 5.0 (Abacus Concepts). Comparison of means was done using the least significant difference (LSD) method at $5 \%$ probability level where the F-value was significant.

\section{RESULTS}

\section{A. Nursery conditions}

At the end of 6 months in nursery, Calvatia sp., Boletus sp., Scleroderma sp. and Strobilomyces sp. formed ECM in $S$. balangeran seedlings. ECM colonization was higher than $50 \%$ in all inoculated seedlings (Table 1.). There was no difference in percentage colonization between four ECM species. Control seedlings were colonized by indigenous of ECM fungi. In the nursery conditions, ECM colonization of $S$. balangeran using spores suspension of Calvatia sp., Scleroderma sp. and Strobilomyces sp. increased plant height, fresh and dry weight (Table 1.). ECM colonization of Boletus sp. Increased only plant height. There was no difference in stem diameter and leaf number between four ECM and control seedlings.

Table 1. Shoot height, stem diameter, leaf number and ectomycorrhizal colonization of $S$. balangeran inoculated with four ECM fungi six months after transplanting under nursery conditions in Palangka Raya, Central Kalimantan

\begin{tabular}{|c|c|c|c|c|c|c|}
\hline \multirow[b]{2}{*}{ Treatment } & \multicolumn{5}{|c|}{ Plant growth } & \multirow[b]{2}{*}{$\begin{array}{c}\text { ECM } \\
\text { colonization } \\
(\%)\end{array}$} \\
\hline & $\begin{array}{l}\text { Shoot } \\
\text { height } \\
(\mathrm{cm})\end{array}$ & $\begin{array}{c}\text { Stem } \\
\text { Diameter } \\
(\mathrm{mm})\end{array}$ & $\begin{array}{c}\text { Leaf } \\
\text { number } \\
\text { (/plant) }\end{array}$ & $\begin{array}{c}\text { Fresh } \\
\text { weight } \\
\text { (g/plant) }\end{array}$ & $\begin{array}{c}\text { Dry } \\
\text { Weight } \\
\text { (g/plant) }\end{array}$ & \\
\hline Untreated & $23.8 \mathrm{a} *$ & $2.3 \mathrm{a}$ & $9.0 \mathrm{a}$ & $2.0 \mathrm{a}$ & $0.68 \mathrm{a}$ & $12 \mathrm{a}$ \\
\hline Calvatia sp. & $31.2 \mathrm{~b}$ & $2.4 \mathrm{a}$ & $9.7 \mathrm{a}$ & $3.4 \mathrm{~b}$ & $1.12 \mathrm{c}$ & $67 \mathrm{~b}$ \\
\hline Boletus sp. & $28.7 b$ & $2.4 \mathrm{a}$ & $10.0 \mathrm{a}$ & $2.2 a$ & $0.74 a$ & $67 \mathrm{~b}$ \\
\hline Scleroderma sp. & $28.7 b$ & $2.4 \mathrm{a}$ & $9.0 \mathrm{a}$ & $2.7 \mathrm{~b}$ & $0.88 \mathrm{~b}$ & $60 \mathrm{~b}$ \\
\hline Surobilonnyces sp. & $27.5 b$ & $2.4 \mathrm{a}$ & $9.3 a$ & $2.5 \mathrm{~b}$ & $0.91 \mathrm{lb}$ & $59 \mathrm{~b}$ \\
\hline
\end{tabular}

Tulles wilt the same lener are not significantly different $(p<0.05)$ 


\section{B. Field conditions}

In the field conditions, ECM colonization did not increased plant height and leaf number two, four and six months after transplanting (Table 2.). There was no significant difference between four ECM species and control seedlings.

Table 2. Shoot height, leaf number and survival rates of S. balangeran inoculated with four ectomycorrhizal fungi two, four and six months after transplanting under field conditions in Kalampangan zone, Central Kalimantan.

\begin{tabular}{|l|c|c|c|c|c|c|c|c|c|}
\hline \multirow{3}{*}{ Treatment } & \multicolumn{9}{|c|}{ Parameter } \\
\cline { 2 - 10 } & \multicolumn{3}{|c|}{2 months } & \multicolumn{3}{|c|}{4 months } & \multicolumn{3}{|c|}{6 months } \\
\cline { 2 - 10 } & $\begin{array}{c}\text { Height } \\
(\mathrm{cm})\end{array}$ & $\begin{array}{c}\text { Leaf } \\
\text { number } \\
(/ \mathrm{plant})\end{array}$ & $\begin{array}{c}\text { Survival } \\
\text { rates } \\
(\%)\end{array}$ & $\begin{array}{c}\text { Height } \\
(\mathrm{cm})\end{array}$ & $\begin{array}{c}\text { Leaf } \\
\text { number } \\
(/ \mathrm{plant})\end{array}$ & $\begin{array}{c}\text { Survival } \\
\text { rates } \\
(\%)\end{array}$ & $\begin{array}{c}\text { Height } \\
(\mathrm{cm})\end{array}$ & $\begin{array}{c}\text { Leaf } \\
\text { number } \\
(/ \mathrm{plant})\end{array}$ & $\begin{array}{c}\text { Survival } \\
\text { rates } \\
(\%)\end{array}$ \\
\hline \hline Untreated & $41.01 \mathrm{a} *$ & $9.2 \mathrm{a}$ & 100 & $44.95 \mathrm{a}$ & $6.3 \mathrm{a}$ & 96 & $49.46 \mathrm{a}$ & $7.6 \mathrm{a}$ & 88 \\
\hline Calvatia sp. & $43.79 \mathrm{a}$ & $9.9 \mathrm{a}$ & 100 & $46.03 \mathrm{a}$ & $6.5 \mathrm{a}$ & 98 & $53.32 \mathrm{a}$ & $8.0 \mathrm{a}$ & 94 \\
\hline Boletus sp. & $43.28 \mathrm{a}$ & $8.6 \mathrm{a}$ & 100 & $45.45 \mathrm{a}$ & $6.1 \mathrm{a}$ & 91 & $55.00 \mathrm{a}$ & $8.3 \mathrm{a}$ & 86 \\
\hline Scleroderma sp. & $41.02 \mathrm{a}$ & $7.1 \mathrm{a}$ & 100 & $47.18 \mathrm{a}$ & $6.6 \mathrm{a}$ & 95 & $54.38 \mathrm{a}$ & $9.0 \mathrm{a}$ & 87 \\
\hline Strobilomyces sp. & $39.66 \mathrm{a}$ & $6.4 \mathrm{a}$ & 100 & $42.64 \mathrm{a}$ & $5.2 \mathrm{a}$ & 94 & $48.22 \mathrm{a}$ & $6.9 \mathrm{a}$ & 93 \\
\hline
\end{tabular}

*Values with the same letter are not significantly different $(\mathrm{p}<0.05)$

ECM colonization of Boletus sp. and Scleroderma sp. increased plant height and leaf number $8,14,16,19,22$, and 25 months after transplanting (Fig. 1). There was no difference in height and leaf number between Calvatia sp., Strobilomyces sp. inoculated and control seedlings. ECM colonization of Boletus sp., Scleroderma sp. and Strobilomyces sp. increased plant height and stem diameter 40 months after transplanting in the field (Table 3.). ECM colonization of Calvatia sp. increased only plant height. There was not different in stem diameter between Calvatia sp. inoculated and control

Seedlings. Survival rates of $S$. balangeran seedlings were increased with ECM colonization of Calvatia sp. and Strobilomyces $s p .40$ months after transplanting in the field (Table 3.).
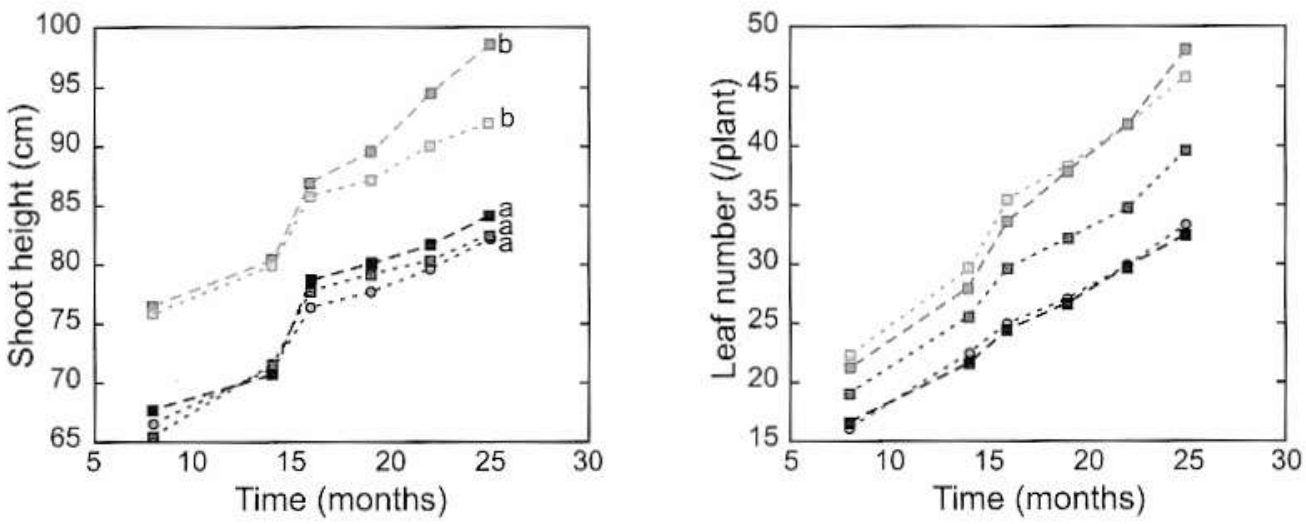

Fig 1. Shoot height and leaf number of $S$. balangeran (Korth.) Burck inoculated with four ECM fungi 8, 14, 16, 19, 22 and 25 months after transplanting under field conditions in Kalampangan zone, Central Kalimantan (Ountreated; 圆Calvatia sp.; $\square$ Boletus

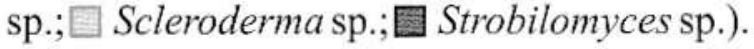


Table 3. Shoot height, stem diameter and survival rates of $S$. balangeran (Korth.) Burck inoculated with four ectomycorrhizal fungi 40 months after transplanting under field conditions in Kalampangan zone, Central Kalimantan

\begin{tabular}{||l|c|c|c|}
\hline \multirow{2}{*}{\multicolumn{1}{c|}{ Treatment }} & \multicolumn{3}{|c|}{ Parameter } \\
\cline { 2 - 4 } & $\begin{array}{c}\text { Height } \\
(\mathrm{cm})\end{array}$ & $\begin{array}{c}\text { Stem diameter } \\
(\mathrm{cm})\end{array}$ & $\begin{array}{c}\text { Survival rates } \\
(\%)\end{array}$ \\
\hline Untreated & $206.63 \mathrm{a}^{*}$ & $2.74 \mathrm{a}$ & 83 \\
\hline Calvatia $\mathrm{sp}$ & $222.57 \mathrm{c}$ & $2.83 \mathrm{a}$ & 89 \\
\hline Boletus $\mathrm{sp}$ & $240.45 \mathrm{c}$ & $3.03 \mathrm{~b}$ & 81 \\
\hline Scleroderma sp. & $233.53 \mathrm{c}$ & $3.67 \mathrm{c}$ & 79 \\
\hline Strobilomyces sp. & $213.55 \mathrm{~b}$ & $3.28 \mathrm{c}$ & 85 \\
\hline
\end{tabular}

*Values with the same letter are not significantly different $(p<0.05)$

\section{DISCUSSION}

Even though the ECM of Dipterocarpaceae in tropical rain forests of Southeast Asia has been reported (Alexander et al.,1992; Smits, 1994; Lee and Alexander, 1996), the role of ECM in dipterocarps species originated from peat-swamp forest needs to clarify. Our results demonstrate for the first time that ECM fungi have positive effects on $S$. balangeran (Korth.) Burck six months under nursery conditions and 40 months after transplanting in the field. Colonization by four ECM species were identified as the most appropriate fungi for improving early growth of $S$. balangeran (Korth.) Burck six months under nursery conditions. Furthermore, Boletus sp. and Scleroderma sp. proved to be competitive and effective to increase plant growth of $S$. balangeran (Korth.) Burck 40 months after transplanting in the field. Therefore, Boletus sp. and Scleroderma $\mathrm{sp}$. are to be ECM fungi candidate for production of S. balangeran (Korth.) Burck under nursery and field conditions. Ecological categories of ECM fungi may be more useful for summarizing fungal performance in the field than in the growing conditions of nurseries (Brundrett et al., 2005; Omon(2002).

Plants with Calvatia sp., Boletus sp., Scleroderma sp. and Strobilomyces sp. were not different in height, and leaf number than untreated seedlings during the $2-6$ months in field conditions. At the time, November 2002-May 2003 was rainy season. It was possible due to waterlogged conditions that all roots of $S$. balangeran (Korth.) Burck were in very saturated with water. Water table in experiment site was close to or above the peat surface throughout 6 months fluctuates with the intensity and frequency of rainfall. Water has become a factor creating other problems i.e. waterlogged stress. Rhizosphere is the part of plant in stress conditions when the oxygen supply for root consumption is being reduced mainly by microorganism respiration. Anaerobic respiration may leads to the synthesis and translocation of some toxic components, and affected various processing activities within plants (Naiola and Osaki, 2000). The transplanting shock and waterlogged conditions by the ECM plants six months after transplanting could be critical to the success of the plantation. After eight months transplanting in the field (July 2003), Boletus sp. and Scleroderma sp. increased the growth of S. balangeran (Korth.) Burck in drought periods. Both ECM species consistency increased plant growth 14, 16, 19, 22, 25, and 40 months after transplanting in the field. Boletus sp. and Scleroderma sp. were more adaptable compared with Strobilomyces sp., Calvatia sp., and control seedlings in waterlogged and drought periods. Strobilomyces sp. and Calvatia sp. lately increased of plant height of $S$. balangeran (Korth.) Burck 40 months after transplanting under field conditions. Field experiments are affected by strong variation in climatic, such as waterlogged conditions in 
the rainy season or drought periods in the summer, edaphic and microbiological factors can influence the spreading of ECM inoculated to waterlogged or drought and cause a lack of inoculation effects (Pera et al., 1999). According to our knowledge, there are no references in the literature indicating ECM effect on S. balangeran (Korth.) Burck in Southeast Asia region. In Madagascar, the use Pisolithus microcarpus increased plant height of $A$. crassicarpa 19 months after transplanting in the field experiment (Ducousso et al., 2004). In a dry tropical area, Pisolithus albus and Scleroderma dyctiosporum increased plant growth of Acacia holosericea after 24 months transplanting in the field in Senegal (Duponnois et al., 2005). In temperate area, Laccaria bicolor mycelia or spore suspensions of Melanogaster ambiguus, Rhizopogon colossus, and $R$. subareolatus increased plant growth of Pseudotsuga menziesii 5 years after transplanting in northern Spain. Laccaria bicolor increased plant growth of $P$. menziesii eight years after transplanting in France (Selosse et al., 1999). In Spain, Rhizopogon spp. increased plant growth of Pinus pinea 20 months after transplanting in formerly arable land (Parladé et al., 2004).

Survival rates of seedlings are important for the first establishment plant growth of $S$. balangeran (Korth.) Burck after transplanting in the field. The role of ECM in the survival rates of $S$. balangeran (Korth.) Burck requires more careful analyses because survival rates were not different between ECM seedlings and control seedling. Survival rates of ECM plants in average were decreased four months $(94.5 \%)$ and six months (90\%) after transplanting in the field conditions. Control seedlings were also decreased four months (96\%), and six months $(88 \%)$ after transplanting. It was possible also that waterlogged conditions can affect the survival rates of ECM plants. Survival rates of ECM plants were consistency steady in 8, 14, 16, 19, 22 and 25 months $(88 \%)$ after transplanting and control seedlings were in $86 \%$. Moreover, survival rates of ECM and control plants were not different $(83 \%)$ in 40 months after transplanting in the field. It was possible that there was cross contamination with inoculated plants because line spacing was only $1 \mathrm{~m} \mathrm{x} 1 \mathrm{~m}$. If control plants were colonized by ECM fungi of inoculated plants they could increase plant growth of control plants. However, we didn't measure ECM colonization 40 months after transplanting under field conditions. In a dry tropical area, survival rates of $A$. holosericea inoculated by Pisolithus albus or Scleroderma dictyosporum were higher (98-100\%) than control plants (81\%) 12 months after transplanting in the field in Senegal. In the temperate forest, inoculation with Rhizopogon roseolus increased in $20 \%$ the survival of Pinus pinea seedlings over control seedlings after 43 months outplanted in Spain (Parladé et al., 2004). Efforts to inoculate tree seedlings with ECM fungi have generally focused on one fungus or a limited number of fungi, which may not be appropriate if benefits from increased fungal diversity are expected, or improved functional diversity is required (Brundrett et al., 2005). It may be possible that in disturbed habitats, there is a succession of ECM fungi where a few pioneering fungi are gradually replaced by an increasing diversity of ECM fungi characteristic of undisturbed habitats (Gardner and Malajczuk, 1988; Lu et al., 1999). Because of the difficulties of monitoring the ECM fungal species in the field samples without using molecular techniques (Di Battista et al., 2002), no data on the determination of each ECM inoculated in the root systems of $S$. balangeran plants are available. Field growth performance of $S$. balangeran (Korth.) Burck is still observed for several years.

In this study, spore density of each ECM species was not measured and it is not known how many spores germinated under nursery conditions and resulted in ECM formation with $S$. balangeran (Korth.) Burck. Spore density can influence ECM formation (Lu et al., 1998). Furthermore, Chen et al. (2006) recommended that spore densities of Scleroderma species $10^{4}$ be used for inoculation of containerized eucalypts and that spores be stored at $4^{\circ} \mathrm{C}$ until use. The main disadvantages of spore inoculum are genetic variability, the lack reliable laboratory methods to determine spore viability and the delay in mycorrhization compared with vegetative 
mycelium (Brundrett et al., 1996). The use of Boletus sp. spores in nursery scales is not widely practiced however because amount of Boletus sp. spores are limited compared with Scleroderma sp. spores. Boletus sp. may also be possible to develop with vegetative mycelium. These vegetative inocula of selected fungal strains have been recommended as the preferred method (Brundrett et al., 1996). However, large quantities of viable inoculum are needed for application on an operational scale and the storage of vegetative inoculum usually adversely influences its effectiveness. Spore-based inoculum was also easier to use and much less expensive to produce than mycelial slurries. Scleroderma sp. are also good candidates for inoculating programs in degraded peat-swamp forest since these species apparently adapt to many ecological habitats and they are easy to use as spore inoculum (Jeffries, 1999; Chen et al., 2006). Further research on factors that regulate spore germination is required to improve both the speed and consistency of ECM formation. It may also be possible to increase the reliability of inoculation by using mixtures of fungal taxa (Brundrett et al., 2005).

\section{CONCLUSION}

In conclusion, colonization of four native ECM species can increase plant growth of $S$. balangeran (Korth.) Burck 6 months after transplanting under greenhouse conditions. Colonization Boletus sp. and Scleroderma sp. can consistency increase plant growth of $S$. balangeran (Korth.) Burck 40 months after transplanting in the field. Strobilomyces sp. and Calvatia sp. was delay to increase only of plant height of $S$. balangeran (Korth.) Burck after 40 months under field conditions. Survival rates of $S$. balangeran (Korth.) Burck were not different between ECM and untreated plants. These results were affected by climatic influences, such as waterlogged or drought periods can reduce the first establishment of ECM plants in the field conditions. Boletus sp. (late stage) and Scleroderma sp. (early stage) can be used to inoculate $S$. balangeran (Korth.) Burck in nurseries because these fungi are well adapted to the environment conditions encountered in this area which could explain this better effect on plant growth. It is suggested that inoculation of indigenous ECM fungi to native tree species under nursery conditions is useful for rehabilitation degraded peat-swamp forests.

\section{REFERENCES}

Alexander I., N. Ahmad and S.S. Lee. 1992. The role of mycorrhizas in the regeneration of some Malaysian forest trees. Philosophical Transactions of The Royal Society London Series B Biological Sciences 335: 379388.

Alexander I. and S.S. Lee. 2005. Mycorrhizas and ecosystems processes in tropical rain forest: implications for diversity. In: Burslem D.F.R.P., M.A. Pinard and S.E. Hartley (eds.). Biotic interactions in the Tropics: Their role in the maintenance of species diversity. Cambridge University Press. p. 165-203.

Bawa, K. S. 1998. Conservation of genetic resources in the Dipterocarpaceae. In: Appanah S. and J.M. Turnbull (eds.). A review of dipterocarps: taxonomy, ecology and silviculture. Center for International Forestry Research (CIFOR), Bogor, Indonesia. $223 \mathrm{Pp}$.

Brundrett M., N. Bougher, B. Dell, T. Grove and N. Malajczuk. 1996. Working with mycorrhizas in Forestry and Agriculture. ACIAR Monograph 32, Canberra.

Brundrett, M., N. Malajczuk, G. Mingqin, X. Daping, S. Snelling and B. Dell. 2005. Nursery inoculation of Eucalyptus seedlings in Western Australia and Southern China using spores and mycelial inoculum of diverse ectomycorrhizal fungi from different climatic regions. Forest Ecology and Management 209: 193205. 
Chen Y.L., L.H. Kang and B. Dell. 2006. Inoculation of Eucalyptus urophylla S.T. Blake with spores of Scleroderma in a nursery in south China: Comparison of field soil and potting mix. Forest Ecology and Management 222: 439-449.

de la Cruz R.E, E.B.Lorilla and N.S. Agganagan. 1990. Ectomycorrhizal tablets for Eucalyptus species. In : Werner D. and P. Muller (eds), Fast Growing Trees and Nitrogen Fixing Trees. Gustav Fisher Verlag, Stuttgard, 371 p.

Di Battista C., D. Bouchard, F. Martin, B. Généré, J.M. Amirault and F. Le Tacon. 2002. Survival after outplanting of the ectomycorrhizal fungus Laccaria bicolor S238N inoculated on Douglas fir (Pseudotsuga menziessi (Mirb.) Franco) cuttings. Annals of Forest Science 59: 81-92.

Ducousso M., A. Galiana, G. Chaix and Y. Prin. 2004. Relative infectivity of two Pisolithus spp. strains inoculated to the nitrogen-fixing legume tree Acacia crassicarpa A. Cunn. Ex Benth. in a field experiment in Madagascar. European Journal of Soil Biology 40: 105111.

Duponnois R., H. Founoune, D. Masse and R. Pontanier. 2005. Inoculation of Acacia holosericea with ectomycorrhizal fungi in a semiarid site in Senegal: growth response and influences on the mycorrhizal soil infectivity after 2 years plantation. Forest Ecology and Management 207:351-362.

Garbaye J., J.C. Delwaulle and D. Diangana. 1988. Growth response of eucalypts in the Congo to ectomycorrhizal inoculation. Forest Ecology and Management 24: 151-157.

Gardner J.H. and N. Malajczuk. 1988. Recolonisation of rehabilitated bauxite mine sites in Western Australia by mycorrhizal fungi. Forest Ecology and Management 24:2742.

Högberg P. 1982. Mycorrhizal associations in some woodland and forest trees and shrubs in Tanzania. New Phytologist 92: 407415.

Jeffries P. 1999. Scleroderma. In: Cairney J. W. G. and S.M.Chambers (Eds.) ectomycorrhizal fungi key genera in profile, Springer, Berlin, p 187-200.

Kobayashi S. 2000. Initial phase of secondary succession in the exploited peat swamp forest (Shorea albida) at Sungai Damit, Belait in Brunei Darussalam. Proceedings of the international symposium on Tropical Peatlands. Hokkaido University and Indonesian Intitute of Sciences. Bogor. Pp. 205-214.

Lee S.S. 1998. Root symbiosis and nutrition. In: Appanah, S. and J.M. Turnbull (eds.). A review of dipterocarps: taxonomy, ecology and silviculture. Center for International Forestry Research (CIFOR), Bogor, Indonesia. $223 \mathrm{Pp}$.

Lee S.S. and I. J. Alexander. 1996. The dynamics of ectomycorrhizal fungi of Shorea leprosula seedlings in Malaysian rain forests. New Phytologist 132:297-305.

Lee S.S. and K.L. Lim. 1989. Mycorrhizal infection and foliar phosphorus content of seedlings of three dipterocarps species growing in a selectively logged forest and a forest plantation. Plant and Soil 117: 237241.

Lu X., N. Malajczuk and B. Dell. 1998. Mycorrhiza formation and growth of Eucalyptus globulus seedlings inoculated with spores of various ectomycorrhizal fungi. Mycorrhiza 8:81-86. 